\title{
Archaeological Testing of Site 41CK178 Coke County, Texas
}

Joe T. Denton

Follow this and additional works at: https://scholarworks.sfasu.edu/ita

Part of the American Material Culture Commons, Archaeological Anthropology Commons, Environmental Studies Commons, Other American Studies Commons, Other Arts and Humanities Commons, Other History of Art, Architecture, and Archaeology Commons, and the United States History Commons

Tell us how this article helped you.

This Article is brought to you for free and open access by the Center for Regional Heritage Research at SFA ScholarWorks. It has been accepted for inclusion in Index of Texas Archaeology: Open Access Gray Literature from the Lone Star State by an authorized editor of SFA ScholarWorks. For more information, please contact cdsscholarworks@sfasu.edu. 


\section{Archaeological Testing of Site 41CK178 Coke County, Texas}

\section{Licensing Statement}

This is a work produced for the Texas Department of Transportation (TxDOT) by the report producer. TxDOT and the report producer jointly own all rights, title, and interest in and to all intellectual property developed under TXDOT's contract with the report producer. The report may be cited and brief passages from this publication may be reproduced without permission provided that credit is given to both TxDOT and the report producer. Permission to reprint an entire chapter, section, figures or tables must be obtained in advance from either the Supervisor of the Archeological Studies Branch, Environmental Affairs Division, Texas Department of Transportation, 125 East 11th Street, Austin, Texas, 78701 or from the report producer 


\title{
ARCHAEOLOGICAL TESTING OF SITE 41CK178 \\ COKE COUNTY, TEXAS
}

\author{
Joe T. ${ }^{\text {By }}$ Denton
}

Texas

State Department of Highways and Public Transportation Highway Design Division

May 1984 


\begin{abstract}
ABSIRACT
In February, 1984, testing of archaeological Site 41CK178 was undertaken by the State Department of Highways and Public Transportation (SDHPT) to determine eligibility for inclusion within the National Register of Historic Places. The site is located in Coke County on State Highway 208 on a shallow terrace of Yellow Wolf Creek, a tributary to the Colorado River. The site contains numerous features and cultural material of undetermined affiliations.

Testing shows the site to consist of a very shallow cultural zone with some features still intact. Artifact density is generally sparse and the majority is very near the present ground surface. The site is not believed to be eligible for inclusion in the National Register of Historic Places.
\end{abstract}




\section{INTRODUCTION}

Archaeological Site 41CK178 was recorded in October, 1983, by a member of the SDHPT professional cultural resources staff. Testing was conducted by a member of the SDHPT professional cultural resources staff and personnel provided by the San Angelo resident engineer's office during the period of February 13 through February 17, 1984. An estimated 96 personhours were spent on this project.

Testing was performed in accordance with Procedures for the $\underline{\text { Protection of Historic and Cultural Properties (36 CFR, Part }}$ 800), procedures endorsed by the Federal Highway Administration. The objective of the test was to determine eligibility to the National Register of Historic Places and to determine the depth and nature of the deposits and cultural contexts.

The project under consideration by the SDHPT consists of the widening of a bridge to eliminate a narrow constriction on State Highway 208 (Fig. 1). This structure is $150 \mathrm{ft}$. in length with a clear roadway width of $26 \mathrm{ft}$. The structure is to be widened to provide a $40 \mathrm{ft}$. clear roadway. The bridge is approached by a two-lane roadway, $40 \mathrm{ft}$. in width, with two $12 \mathrm{ft}$. lanes and 8 ft. paved shoulders. While no new right-of-way is required, the anticipated widening of the shoulders at the bridge approach and use of the resulting soil as fill necessitated the examination of 
This Page Redacted Per THC Policy 
Site 41CK178. The site was originally disturbed in 1946 by implementation of road work. 


\section{SITE DESCRIPTION}

Site 41CK 178 is located on the south terrace of Yellow Wolf Creek on both sides of present State Highway 208 (Fig. 2) north of the town of Robert Lee in Coke County. The area is typified by broad valleys and scattered mesas and hills. The lowlands form rolling prairies of nearly level to moderate relief. The creeks are generally well entrenched with steep banks. Runoff is presently rapid with most creeks carrying minimal flows or dry between periods of rainfall. Yellow Wolf Creek generally carries some water year round. Ground cover in the vicinity of the site is sparse.

The site is shallow, generally less than $30 \mathrm{~cm}$ deep, with several hearths partially exposed on the surface. Originally the site probably extended over the whole terrace and was approximately $500 \mathrm{ft}$. in length and $250 \mathrm{ft}$. in width. State Highway 208 divides the site approximately in half. Some areas outside the present right-of-way have been subject to clearing, thus disrupting some deposits. Several hearths were evident on the surface east of the east side of the roadway. The scattering of lithic debris, which consists of flakes and a few biface fragments, appears to increase near areas of exposed burned rock or hearths. Two hearths and some scattered burned rock were observed in the roadcut at the time of testing. 
ARCHAEOLOGICAL BACKGROUND

Prior to 1968, the archaeology of Coke County was limited principally to surface reconnaissance. The only excavated site prior to 1968 was a partially destroyed rockshelter that was excavated by Sayles on Oak Creek east of 41CK178 (Sayles 1930). This site was a deep stratified rockshelter site with distinct occupation zones. In 1968, archaeological testing and excavation of sites was conducted by the Texas Archeological Salvage Project on sites to be inundated by the Robert Lee Reservoir. The impoundment is presently known as E. V. Spence Reservoir. Results of the tests and excavations were reported by Shafer (1969, 1971).

Excavations during the reservoir project indicated that the primary occupations within the reservoir were Late Archaic to Protohistoric. The earliest occupation occurred after 500 B.C. (Shafer 1971:130). Occupations prior to that time were apparently minimal or as yet undocumented. The sites were typically very shallow and lacking in strong stratigraphic separations. The sites were generally habitations with hearths and activity areas. Hearths were described as shallow basinshaped features lined with limestone pebbles and cobbles. Activity areas were predominately the result of lithic tool manufacturing. 
Tools recovered by Shafer's investigations contain elements of the Central Texas region as well as the North-Central and Panhandle Plains Regions of Texas (Shafer 1971). Some elements, pottery and trade goods, appear to be attributable to Apache groups (Shafer 1971:136-137).

While numerous surveys have been conducted in adjacent counties very few reports of excavations have been published. In Tom Green County, Green (1959) reported an excavation of a shallow midden in the Twin Buttes Reservoir area. The material was less than 18 in. in depth (Green 1959:183). The material was principally Middle to Late Archaic.

Surveys in adjacent counties (Douthit 1978; Wooldridge 1981) show sites to represent the full range of prehistoric time periods, but the sites themselves are generally shallow. Deep sites, while present, are the exception rather than the rule (Douthit 1978). 


\section{PROCEDURES}

Archaeological testing of Site $41 \mathrm{CK} 178$ consisted of handexcavated test units, profiles, and surface observations. Seven

1 by 1 meter test units were excavated. Test unit excavation was based principally on observation of cultural evidence in the existing roadcut and was arranged to determine the limits of the site.

Two control base lines were established 2.5 meters inside the right-of-way boundaries with a central datum at Highway Station No. 384. The base lines are parallel to the centerline of State Highway 208. Elevations were established on the basis of permanent bench marks. Three test units were placed on the west side and four test units on the east side of the existing roadway. Test Units 1 through 3, 5, and 7 were placed over or proximal to observed burned rock. Test Units 4 and 6 were opened to determine site limits (Fig. 2). Units were excavated by hand in arbitrary $10 \mathrm{~m}$ levels.

Soil matrix resulting from excavation was screened through $1 / 4$ in. hardware cloth, and the recovered cultural debris was retained for analysis. Recovered material was bagged according to unit and level and removed from the site to the SDHPT laboratory for temporary storage and analysis. 


\section{FEATURES}

Three features were investigated during the course of testing. Feature 1 (Fig. 3) was first observed as a thin scatter of burned rock on the western roadcut at Highway Station No. 384. Excavation revealed that a random scatter of burned rock was encountered at 20 to $30 \mathrm{~m}$ below the present ground surface. No tools were recovered and only 11 flakes were recovered at the depth of the feature. Excavation continued to $50 \mathrm{~cm}$ and into sterile soil.

Feature 2 (Fig. 4) was also exposed by the roadcut on the west side of the roadway. This feature, a hearth, was larger and had slumped down the bank of the cut. Excavation of Test Unit 2 was initiated to salvage as much of the hearth as possible. Test Unit 3, opened nearby, was to expand excavation adjacent to the hearth to determine if an occupational surface was present. The top of the burned rock was first encountered at the bottom of fill dirt from the 1946 construction (Fig. 5). The contact is clearly defined between the upper gravelly loam fill material and the reddish brown clay loam which contained the burned rock.

Exposure of the remaining burned rock revealed a slightly scattered hearth. The hearth was fairly loose and without definite structure. Time of disruptions is uncertain but is possibly related to clearing operations prior to road 


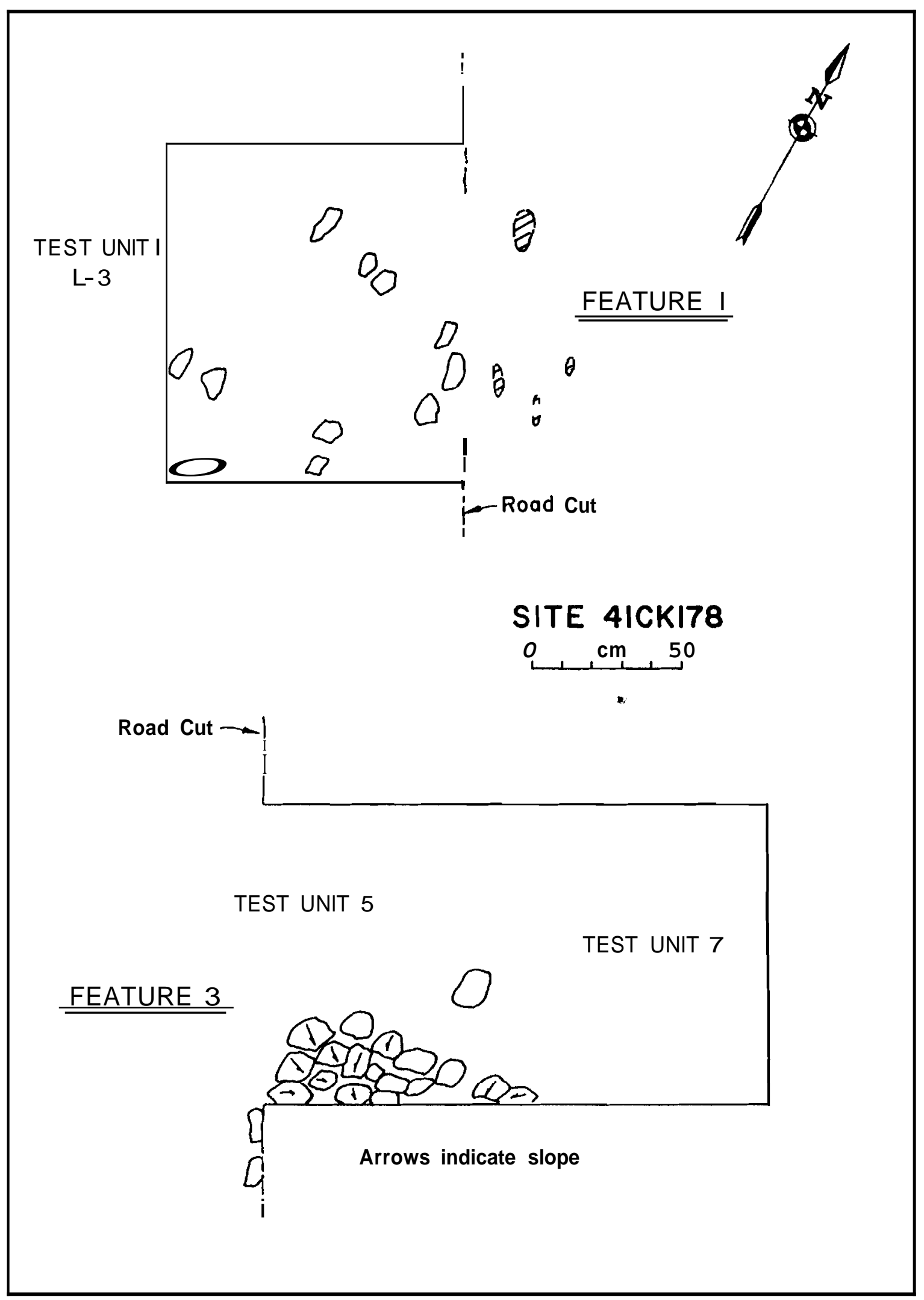

FIGURE 3. Features 1 and 3 . 


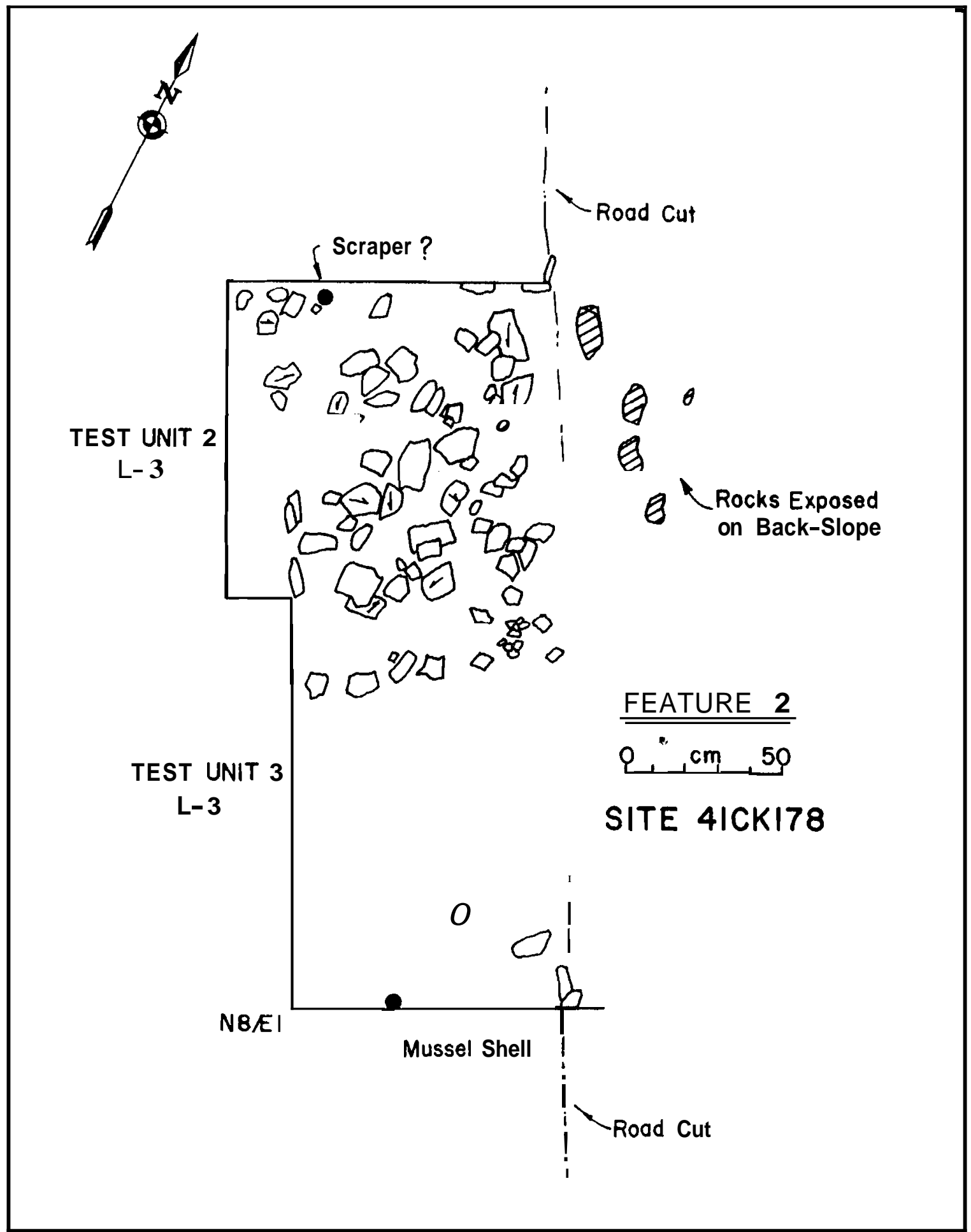

FIGURE 4. Feature 2. 


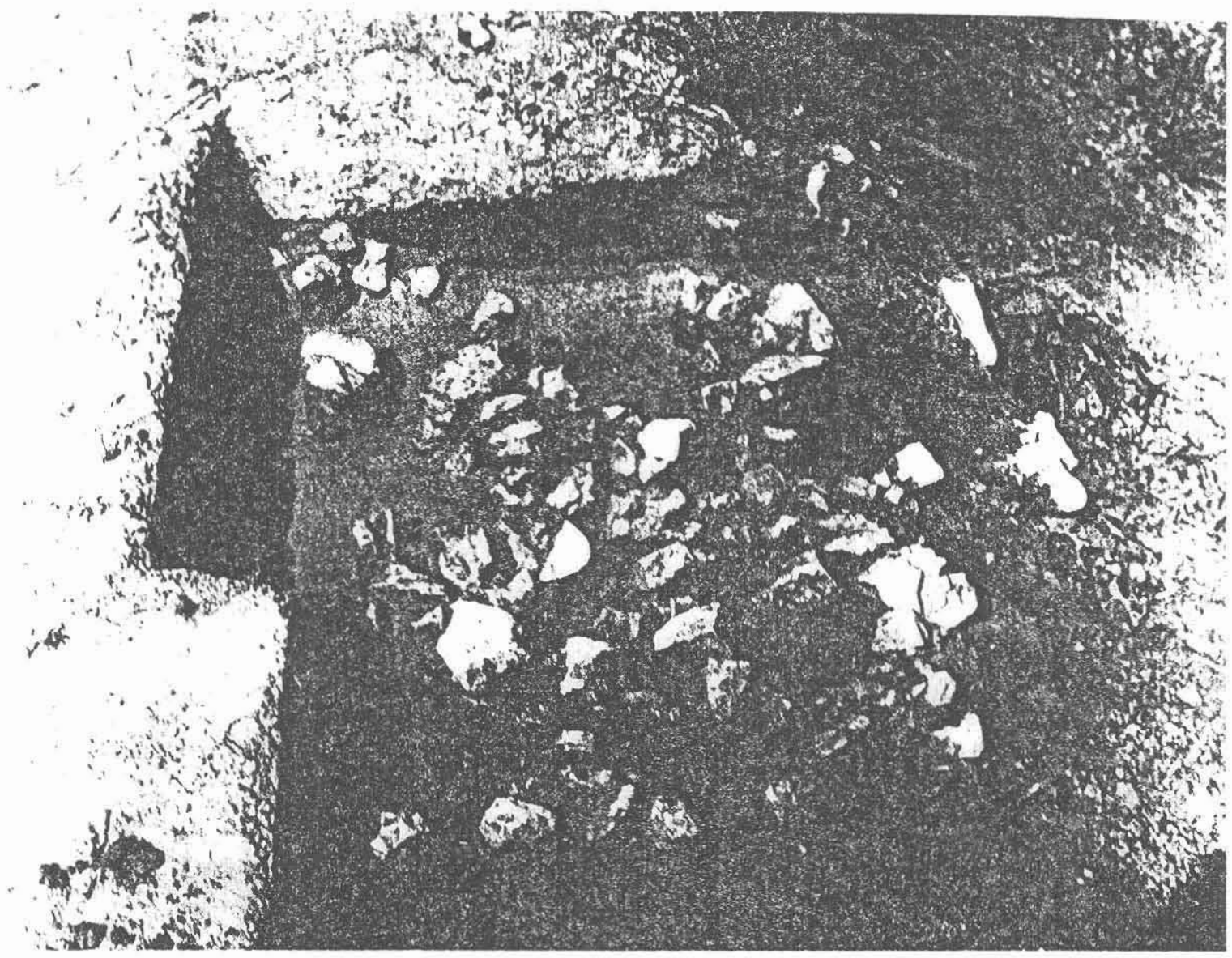

FIGURE 5. Feature 2. Note overburden of recent fill dirt atop feature and intact soil deposits. 
construction. Some rock, however, was fractured in situ and undisturbed. The hearth was approximately 1.2 meters in length and approximately $80 \mathrm{~m}$ in width. Some width was lost due to the roadcut and erosion. Associated with the hearth was a uniface fragment, a mussel shell fragment, and a midsection of a thinned biface. Forty-six flint flakes recovered from Test Units 2 and 3 were found in association with the hearth.

A small tight cluster of burned rock, Feature 3 (Fig. 3), was observed in the east roadcut slightly below the ground surface. Test Unit 5 was excavated initially to determine the limits of the hearth. Test Unit 7 was later opened in order to determine if the hearth had structure.

Feature 3 appeared to be a small, shallow, basin-shaped hearth approximately 20 an below the present ground surface. Associated at the same level as the feature in Test Units 5 and 7 were 53 flakes and a biface fragment. Also recovered was a small charcoal sample. 


\section{ARTIFACTS}

Surface collections and test excavations resulted in the recovery of 76 prehistoric artifacts and 382 flint flakes and chips;

slightly more than $80 \%$ of the prehistoric material was recovered from the ground surface. The artifacts from the surface will be discussed separately from the excavated artifacts.

\section{Excavated Material}

BIFACE FRAGMENIS (4 specimens)

Subrectangular Biface Fragment (1 specimen)

This artifact is subrectangular in outline and is broken near its midpoint. The fragment shows bifacing over most of the dorsal and ventral surfaces with wide and shallow flake scars. One lateral edge still retains a portion of the original flake platform. The blade edges are slightly sinuous. The biface was associated with Feature 3 in Level 1.

Thinned Biface Fragments (3 specimens)

Two of the fragments are from the same tool and have been burned and fire-fractured. These fragments indicate that the tool was a thin biface with straight, even edges. Flaking appears to be soft-hammer, and the edges are retouched. These two fragments were recovered from Test Unit 5 near Feature 3 at Level 2. The 
third thinned biface fragment was recovered in the rocks of

Feature 2, Test Unit 2, and is also burned. It also appears to have been manufactured by soft-hamner percussion and has retouched edges. It is impossible to determine which tool types these fragments represent.

UNIFACE RAGMENT (1 specimen)

This fragment exhibits retouch on one lateral edge. The edge is not steeply beveled. The flake retains cortex on the platform and portions of the dorsal surface. The uniface fragment was recovered adjacent to Feature 2.

CORES ( 2 specimens)

Both specimens exhibit multidirectional flake scars and still retain some cortex. The flint is gray and waxy. One core was recovered from Test Unit 4, Level 4, and the other from Test Unit 6, Level 1.

ALTERED FLAKES (8 specimens)

All of the altered flakes exhibit small areas of edge retouch with generally steep edge angles. Edge beveling is on the dorsal surface in all cases. Four were recovered from around Feature 1, and four from around Feature 3.

DEBTIAGE (160 specimens) 
A total of 160 flint flakes and chips from beneath the ground surface was recovered from six test units. Test Unit 4 was the only unit where flakes were not found. The flakes were both hard-hammer and soft-hammer percussion flakes and include some lipped flakes. Because of the limited number of flakes, a detailed breakdown was not attempted.

HISTORIC MATERIAL (16 specimens)

A total of 13 wire nails, 2 pieces of glass, and 1 nondescript piece of metal was recovered. The nails were present in Level 1 of Test Unit 5 and Levels 1 and 2 of Test Unit 6. The glass was in Test Unit 2 near Feature 2 and in Test unit 6.

\section{Surface Material}

The surface collection was made only from areas within the SDHPT right-of-way. A total of 10 biface fragments, 3 uniface fragments, 4 cores, 2 hammerstones, and 42 altered flakes was recovered. In addition 222 flint flakes were recovered.

BIFACES (10 specimens)

Triangular Biface Fragments (2 specimens)

Two triangular biface fragments were recovered. One is large with a maximum width of $50 \mathrm{~mm}$ and the other is much smaller with a maximum width of only $25 \mathrm{~mm}$. Both are apparently manufacturing failures and lack even edges. 
Thinned Biface Fragments (5 specimens)

Five thinned biface fragments were recovered. All exhibit wide, thin flake scars; and where present, the edges are generally even.

Crude Bifaces (3 specimens)

Three thick biface fragments were recovered which exhibit hardhammer percussion with deep, relatively narrow flake scars and sinuous edges. Some cortex is present on portions of one specimen.

UNIFACES (3 specimens)

End and Side Unifaces (2 specimens)

One uniface was recovered which exhibits edge beveling over $75 \%$ of the flake edges. The edges are generally even and steeply beveled. The dorsal surface retains most of the original cortex. An additional flake fragment exhibits edge beveling on one end and side. This uniface is lacking one edge and platform.

Lateral Uniface (1 specimen)

A flake blade specimen was recovered which exhibits retouch on one lateral edge. The opposing flake blade edge retains the cortex and is unmodified. 
CORES ( 4 specimens)

Four cores or core fragments were recovered. All exhibit multidirectional flake scars and cortex. The flint cobbles are gray and waxy in appearance with some inclusions.

HAMMERSTONES ( 2 specimens)

Two flint hammerstones were recovered which exhibit extensive battering over one edge. One specimen is fragmented; the other is $66 \mathrm{mmlong}, 58 \mathrm{~mm}$ wide, and $38 \mathrm{~mm}$ thick.

ALTERED FLAKES (42 specimens)

A total of 42 altered flakes which range from $25 \mathrm{~mm}$ o $93 \mathrm{~mm}$ in length was recovered. Alteration ranges from apparently random retouch to small areas of steep beveling. Since the material is from the surface and the area has been trod over by both animals and machines, it is uncertain how much alteration is incidental or intentional. 


\section{CONCUUSIONS AND RECOMMENDATIONS}

The site, 41CK178, is a shallow campsite with associated features that are partially exposed on the surface. The soil deposit containing the cultural material is roughly $20 \mathrm{~m}$ thick.

Altered flakes and biface fragments represent the majority of the prehistoric artifacts recovered during investigation. Altered flakes represent $69 \%$ of the surface material and $53 \%$ of the excavated material. Biface fragments represent $16 \%$ of the surface material and $27 \%$ of the excavated material. This slight increase in bifaces from buried deposits might be indicative of surface collecting by relic hunters. Eighty percent of the prehistoric cultural material was from the surface collection.

The majority (60\%) of the excavated cultural material was located within the upper 10 m of the original ground surface. A total of $93 \%$ of a 11 excavated material was contained within the upper $20 \mathrm{~cm}$. Original ground surface was buried in the area of Test Units 2 and 3 by approximately 20 m of fill material from the 1946 construction of the present roadway and bridge. 
The hearths at the site are relatively small, averaging 1 meter in diameter, and flat to slightly basin-shaped. Scattering of the rock as well as the small sample prevents any major determination of overall structure of the features and specific activities around the hearths. The lack of any diagnostic material from the site also precludes any age determination or cultural affiliation.

The Robert Lee Reservoir surveys and excavations by the Texas Archeological Salvage Project (Shafer 1969, 1971) clearly show sites to be shallow, with sites containing deep deposits to be a rarity. Sites like 41 CK178 are numerous and likely disturbed both by natural occurrences and recent large-scale agribusiness operations. Large-scale clearing and root-plowing to remove mesquite and to improve rangeland would cause major disruption of these shallow sites.

On the basis of the findings of the test and comparison to the archaeology of the area, Site $41 \mathrm{CK} 178$ as manifested within the SDHPT right-of-way is not believed to be eligible for inclusion within the National Register of Historic Places. 


\section{REHERENCES CITED}

Douthit, Mary Lee

1978 An Archeological survey of the North Concho River

Valley, Sterling County, Texas. Ph. D.

Dissertation, Department of Anthropology,

The University of Texas at Austin.

Green, F. E.

1959 Archeological Salvage in the Twin Buttes

Reservoir Area, San Angelo, Texas. Bulletin of

the Texas Archeological Society 30.

Sayles, E. B.

1930 A Rockshelter in Coke County. Bulletin of the

Texas Archeological and Paleontological

Society 2:33-40.

Shafer, Harry J.

1969 Archeological Investigations in Robert Lee

Reservoir Basin, West Central Texas. Paper of

the Texas Archeological Salvage Project 17.

The University of Texas at Austin.

1971 Investigations into the South Plains Prehistory,

West Central Texas. Paper of the Texas

Archeological Salvage Project 20.

The University of Texas at Austin.

Wooldridge, H. G.

1981 A Culture Resource Inventory and Assessment

of the Proposed Stacy Reservoir, Concho, Coleman,

and Runnels Counties, Texas, Vol. 1: 
Prehistoric Cultural Resources. Espey, Huston \& Associates, Inc. Austin. 